\title{
Bulaşıcı Hastalık Bildirimlerinin Afet Yönetimi Açısından İncelenmesi
}

\author{
Investigation of Communicable Disease Notifications in terms of Disaster Management
}

\author{
Nahsan KAYA ${ }^{1}$, Turgut ŞAHINÖZ²
}

\section{ÖZ}

Türkiye'de afet yönetimi açısından bulaşıcı hastalıklar konusunda çok az araştırma bulunmaktadır. Bu araştırma, Türkiye'nin yakın tarihinde (1956-2017) maruz kaldığı bulaşıcı hastalıkları incelemek ve gelecekte olası bir felaketin zararlarını en aza indirmek için ne yapılması gerektiği konusunda rehberlik sağlamak amacıyla planlanan bir araştırmadır.

$\mathrm{Bu}$ araştırma, tanımlayıcı tipte ve retrospektif kohort özelliğinde bir araştırmadır. Araştırmanın verileri 1956-2017 yılları arasında Sağlık Bakanlığı tarafından yayınlanan "istatistik yıllıklarından" elde edilmiştir. Veriler bilgisayar ortamında analiz edilmiştir. Bu yıllıklarda 23 bulaşıcı hastalık türü tespit edilmiştir ve insidans oranları yıllara göre hesaplanmıştır.

2004 ve öncesi y1llara ait yıllıklarda bulaşıcı hastalık verilerine daha fazla önem verildiği görülmektedir. Son y1llara ait istatistik y1llıklarında ise sınırlı sayıda hastalık (Verem, Sitma, Kızamık ve AIDS) için çok az veri yayınlanmaktadır. Yasal zorunluluk olsa da; Türkiye'de bulaşıcı hastalıkların bildirimi yeterli değildir. İstatistik yıllıklarında sınırlı verilerin yayınlanması, afet yönetimi açısından bulaşıcı hastalıklara dair risk analizini zorlaştırmaktadır. Bulaşıcı hastalıklar açısından; tüberküloz insidansı 1960-1969 yılları arasında, sitma insidans1 1980-1989 yılları arasında, kızamık insidansı 1960-1970 y1lları arasında en yüksek seviyededir. Türkiye'de bulaşıcı hastalıkların görülme sıklığını azaltmak ve salgınları önlemek için etkili ve kapsamlı bir sürveyans, erken müdahale ve müdahale altyapısı kurulması önerilmiştir.

Anahtar Kelimeler: Afet Yönetimi, Bulaşıcı Hastalık, Sürveyans, Bildirim Sistemi

\section{ABSTRACT}

In Turkey, there is few studies of infectious diseases from a disaster management perspective. This research, in Turkey's recent history (1956-2017) to examine exposure to communicable diseases and to provide guidance on what should be done to minimize the harm of a possible disaster in the future.

This research is a descriptive and retrospective cohort research. The data of the study were obtained from "statistical annals" published by the Ministry of Health between 1956-2017. Data were analyzed by computer. 23 infectious disease cases were obtained from these annuals and incidence rates were calculated according to years.

It is seen that more importance is given to infectious disease data in the annals of 2004 and before. In the statistical annals of recent years, very little data are published for a limited number of diseases (Tuberculosis, Malaria, Measles and AIDS). Although there is a legal obligation; Notification of infectious disease in Turkey is not enough. The publication of limited data in statistical annuals makes it difficult to analyze the risk of communicable diseases in terms of disaster management. In terms of communicable diseases; Tuberculosis incidence between 1960-1969, malaria incidence between 1980-1989, measles incidence at the highest level between 1960-1970. To reduce the incidence of infectious diseases in Turkey and an effective and comprehensive surveillance to prevent epidemics, it is proposed to establish early intervention and response infrastructure.

Keywords: Disaster Management, Infectious Disease, Surveillance, Notification System

\footnotetext{
*Bu çalışma Gümüşhane Üniversitesi Sosyal Bilimler Enstitüsü Afet Yönetimi Yüksek Lisans Programı'nda yüksek lisans tezi olarak yapılmış ve 4.Uluslararası Sağlık Bilimleri ve Yönetim Kongresinde (20-23 Haziran 2019-İstanbul) sözlü bildiri olarak sunulmuştur.

${ }^{1}$ Öğr. Görevlisi, Afet Yönetimi, Kütahya Sağlık Bilimleri Üniversitesi, Simav Sağlık Hizmetleri Meslek Yüksekokulu, Medikal Görüntüleme Teknikleri, nahsankaya0229@gmail.com, ORCID: https://orcid.org/0000-0003-4933-2738

${ }^{2}$ Dr. Öğr. Üyesi Halk Sağlığı Uzmanı, Ordu Üniversitesi Sağlık Bilimleri Fakültesi Sağlık Yönetimi Bölümü, drsahinoz@hotmail.com, ORCID: https://orcid.org/0000-0001-8489-8978

İletișim / Corresponding Author:

Nahsan KAYA nahsankaya0229@gmail.com 


\section{GíRIŞ}

Afet genel anlamda "fiziksel, ekonomik ve sosyal kayıplara neden olan normal yaşamı ve insani faaliyetleri durdurarak veya kesintiye uğratarak, olağan seyrini değiştirerek toplulukları olumsuz etkileyen doğal, teknolojik veya insan kökenli olaylar ve bu olayların neden olduğu sonuçlar" olarak tanımlanmaktadır. ${ }^{1}$

Afet sonrasında; sağlık, beslenme, çevre, sosyo-ekonomik ve barınma sorunları ile karşılaşılmaktadır. $^{2} \mathrm{Bu}$ sorunlar ile başa çıkılamadığı takdirde; toplumda ikincil afete sebep olabilecek bulaşıcı hastalıkların görülme riski artmış olacaktır. Ayrıca bulaşıcı hastalıklar kıtalar arası yayılım gösterip insanlığın tamamını etkileyebilecek potansiyele sahip oldukları için de afetlere sebep olabilmektedirler.

İnsanoğlu, zaman içinde sel, kuraklık, deprem, heyelan, çı̆̆ gibi afetlere maruz kalmışsa da hiçbiri kısa sürede geniş alana yayılan ve milyonlarca insanı etkileyen veya can kayıplarına neden olan bulaşıcı hastalıklar kadar zarar vermemiştir. ${ }^{2}$ İnsan hayatı üzerinde büyük olumsuzluklara yol açan bu afet türü nedeniyle yoğun nüfus hareketleri yaşanmış ve bu hareketlilikten dolayı başka topluluklar da etkilenmiştir. ${ }^{1}$

Günümüzde vektörlerin çoğalması, yetersiz altyap1 ve kanalizasyon sistemleri, yetersiz ve dengesiz beslenme, göçler, ulaşım şartlarının gelişmesi gibi etkenler bulaşıcı hastalıkların salgına dönüşmesini kolaylaştırmaktadır. ${ }^{3}$ Türkiye'nin ticari aktivitesi, turizm potansiyeli, kültürel etkileşimleri, coğrafik konumu ve iklim şartları göz önüne alındığında bulaşıcı hastalıklara maruz kalma riski her geçen gün artmaktadır. $^{1}$

İnsanların yaşayış biçimlerinden kaynaklanan sağlıksız ortamlar, doğal dengenin bozulması, savaşlar, kıtlıklar, doğal afetler gibi daha birçok sebebe bağlı olarak salgınlar ortaya çıkmıştır. ${ }^{1} \mathrm{Bu}$ salgınlar için; modern tedavi şekilleri bulununcaya dek kitleler halinde ölümlere neden olan afetler arasında yer almışlardır.
Bulaşıcı hastalıkların görülme sıklığı, bir ülkenin gelişmişliği hakkında bilgi veren önemli parametrelerden biridir. ${ }^{2}$

Bulaşıcı hastalıkların ihbarı ve bildirimi; hastalı̆̆ı mortalitesini ve morbiditesini azaltılmak amacı ile oluşturulan ve bulaşıcı hastalıkların sürveyans sistemi kapsamında sistemli bir biçimde veri toplamak, salgın görülmeden önce tahmin etmek, hastalıklara ait koruma ve kontrol programları belirlenmek ve uygulanmak, belirlenen programların izlenmesi ve gerektiğinde yeni düzenlemeler yapılması amacı ile kullanılan hayati öneme sahip mekanizmadır. ${ }^{4}$

Türkiye'de Bildirimim Zorunlu Bulaşıcı Hastalık (BZBH) say1s1 1930'da 30, 2005 y1lında ise 51 'dir. BZBH bildirim sisteminde 2007'de yapılan yönetmelik değişikliği ile Erken Uyarı ve Yanıt Sistemi (EUYS) tanımlanmış ve 2011'deki değişikliklerle de güncel hale getirilerek bu sayı 73'e çıkarılmıştır. ${ }^{4}$

Türkiye'de BZBH'lerin bildirimi için Ulusal Sağlık Bilgi Sistemi (Sağlık Net, Sağlık Net 2), Aile Hekimliği Bilgi Sistemi (AHBS), Elektronik Tüberküloz Yönetim Sistemi (ETYS), Halk Sağlığı Bilgi Sistemi (HSBS) gibi bilgi sistemleri kullanılıyor olsa da 2019 y1lında uygulamaya konulan IZCI programı ile BZBH'lerin semptom ve hastalıklara ait verilerin toplanması, bildirimi yapılan vakalara yönelik yürütülen saha çalışmalarının kayıt altına alınması, raporlanması ve analizlerin elektronik ortamda yapılabilmesi sağlanmıştır. Ayrıca sendromik sürveyans verilerinden hazırlanan analiz raporları ile ülke-il-ilçe-kurum bazında, zamansal-mekansal analiz raporları ile de ülke-il-ilçe bazında takip yapılabilmektedir. ${ }^{5}$

Bildirimi zorunlu olan bir hastalığın tespit edilmiş olmasına rağmen bildirilmemesinde; gerekliliğine inanmama, iş yükünde artış olarak görme, siyasi engeller ya da angarya olarak görme gibi sebepler ön plandadır.

Herhangi bir coğrafyada ortaya çıkan bulaşıcı hastalıklar, sadece o bölgede sınırlı kalmayacağı için bütün dünya teyakkuz haline 
geçmektedir. $^{3} \mathrm{Bu}$ riskler göz önüne alındığında her ülkenin sağlık sisteminin olası bulaşıcı hastalıklara karşı geliştirilmesi zorunlu hale gelmiştir. Türkiye'de bu konuda yeterli olmasa da önemli çabalar sarf edilmektedir.

Araştırmanın amacı; Türkiye'nin yakın tarihindeki bulaşıcı hastalıkların bildirimlerini ortaya çıkarmaktır. Türkiye'de bildiriminin yapıldığı belirlenen bulaşıcı hastalıkların vaka sayılarını analiz ederek; Türkiye'de görülebilecek bu tür afetlerin toplumda yol açacağı zararın en aza indirilmesine ve ilgili kurumların yapacağı afet planlarında gerekli önlemlerin alınmasına katkıda bulunmak ve yol göstermek amacıyla planlanmıştır.

\section{MATERYAL VE METOT}

\section{Araştırmanın Etik Yönü}

Araştırmanın verileri Sağlık Bakanlığı'nın 1956-2017 yılları arasında düzenli olarak yayınladığı istatistik yıllıklarından kayıt tarama yöntemi ile elde edilmiştir. Etik kurul izni gerekmediği için alınmamıştır.

Yazarların herhangi bir çıkar çatışması mevcut değildir.

Sağlık Bakanlığı web sayfasında yayınlanan sağlık istatistik yıllıklarına 1996 y1lindan itibaren internette https://www.saglik.gov.tr/TR,11588/istatistik -yilliklari.html ulaşılabilmektedir. $^{6}$ Ancak araştırmayı hazırlarken yapılan kapsamlı araştırmalar sonucunda 1996 yılından önceki verilere de Sağlık Bakanlığı arşivinde basılı belge olarak ulaşılmıştır. $\mathrm{Bu}$ sebeple araştırma oldukça geniş bir arşiv özelliği de taşımaktadır.

Sağlık Bakanlığ 1 istatistik yıllıklarında Ensefalit ve Menenjit vaka sayıları yayınlanmış olmasına rağmen, vaka sayılarının az olması ve tüm yıllara ait veriler olmaması, afet yönetimi açısından büyük bir risk teşkil etmemesi nedeniyle araştırmaya dâhil edilmemiştir.

$\mathrm{Bu}$ araştırmada; bildirimi zorunlu olan bazı bulaşıcı hastalıkların vaka sayıları, insidans hızları (nüfusa oranlanmış vaka sayıları), her on y1lda bir vaka ortalamaları ve insidanslar hesap edilmiştir. Belirtilen hastalıklardan dolay1 hayatını kaybedenlerin sayıları yıllıklarda verilmiş olmasına rağmen güvenilir veriler olmadığı için çalışmaya dâhil edilmemiştir.

\section{Yöntem}

$\mathrm{Bu}$ araştırma, tanımlayıcı tipte ve retrospektif kohort özelliğinde bir araştırmadır.

Araştırmanın verileri Sağlık Bakanlığı'nın 1956-2017 yı1ları arasında düzenli olarak yayınladığ 1 istatistik yıllıklarından elde edilmiştir. Tüm istatistik yıllıkları (29 adet yıllık) taranarak 18 BZBH'nin verileri analiz edilmiştir.

Araştırma "afet yönetimi” bakış açısıyla bulaşıcı hastalıklar, sürveyans, bildirim sistemi, erken uyarı ve yanıt konularını kapsayan saptanabilen ilk araştırma olarak değerlendirilmektedir.

$\mathrm{Bu}$ araştırma ile toplumda afete neden olmuş veya neden olabilecek bulaşıcı hastalıklar değerlendirilerek tehlike ve risk analizleri yapılmaya çalışılmış, dünyanın ve Türkiye'nin mevcut şartları göz önüne alındığında bu tür bir afete maruz kalma durumunda bildirim sistemi ve erken yanit sistemlerinin uygulanabilirliğgi tartışılmış ve insanlığ 1 bekleyen bulaşıc1 hastalıklar ve neden olabileceği afetler hakkında bir vizyon çizilmiştir.

Bilgisayar ortamında istatistiksel değerlendirmeler yapılmıştır. Bulaşıcı hastalık vaka sayıları ilgili yıldaki ülke nüfusuna oranlanarak nüfusa oranlanmış vaka sayıları (insidans) hesaplanmıştır. Ayrıca on yıllık vaka ortalamaları ve insidanslar da hesaplanarak yıllar arasında karşılaştırmalar yapılmıştır. Elde edilen bulaşıcı hastalık verileri gruplar halinde tablolaştırılarak sunulmuştur. 


\section{BULGULAR VE TARTIŞMA}

Sağlık Bakanlığı'na ait tüm istatistik yıllıkları taranarak 18 bulaşıcı hastalık, afet yönetimi bilimi açısından değerlendirilmiştir.

Türkiye'de bugüne kadar yayınlanan sağlık istatistik yıllıkları incelendiğinde, 2004 ve öncesine ait yıllıklarda bulaşıcı hastalık verilerine daha çok önem verildiği ve eski yıllara ait verilerin eksiksiz olduğu görülmektedir. ${ }^{6-16}$

Tablo 1. 1956-2017 İstatistik Yıllıkları ve Bazı Özellikleri

\begin{tabular}{cccc}
\hline Istatistik Yıllı̆̆ı* & $\begin{array}{l}\text { Yayın } \\
\text { Yılı }\end{array}$ & $\begin{array}{c}\text { Sayfa } \\
\text { Sayısı }\end{array}$ & $\begin{array}{c}\text { Hastalık } \\
\text { Türü }\end{array}$ \\
\hline $1956-1959$ & 1961 & 378 & 22 \\
$1960-1963$ & 1965 & 256 & 20 \\
$1964-3967$ & 1971 & 315 & 26 \\
$1968-1972$ & 1975 & 373 & 26 \\
$1973-1974$ & 1977 & 239 & 26 \\
$1975-1978$ & 1980 & 401 & 17 \\
$1979-1981$ & 1983 & 394 & 15 \\
$1982-1986$ & - & 250 & 15 \\
$1987-1994$ & 1997 & 307 & 17 \\
1995 & 1996 & 139 & 19 \\
1996 & 1997 & 143 & 19 \\
1997 & 1998 & 138 & 19 \\
1998 & 1999 & 142 & 18 \\
1999 & 1999 & 145 & 18 \\
2000 & 2000 & 143 & 18 \\
2001 & 2002 & 143 & 18 \\
2002 & 2003 & 147 & 18 \\
2003 & 2004 & 178 & 22 \\
2004 & 2005 & 200 & 22 \\
2008 & 2011 & 162 & 9 \\
2009 & 2011 & 162 & 9 \\
2010 & 2011 & 172 & 10 \\
2011 & 2012 & 183 & 4 \\
2012 & 2013 & 190 & 4 \\
2013 & 2014 & 199 & 4 \\
2014 & 2015 & 204 & 4 \\
2015 & 2016 & 248 & 4 \\
2016 & 2017 & 276 & 4 \\
2017 & 2018 & 288 & 4 \\
\hline * 2005 yılı sağlık istatistikleri & yayınlanmıs olmasına rağmen \\
erişime açı değildir. 2006 ve 2007 yılı tıbbi istatistik yıllıkları \\
yayınlanan istatistikler arasında yer almamaktadır. Bu yıllara ait \\
veriler daha sonra yayınlanmış istatistik yıllıklarında alınmıştır.
\end{tabular}

2004 ve öncesine ait yıllıklarda; hastalığın salgın yaptığı yıllar, hastalıkla mücadelede yapılan uygulamalar ve aksayan yönleri, hastanede yatıp tedavi gören ve hastanede hayatını kaybeden vakalara ait verilere de yer verilmekte, iller ve mevsimler bazında daha detaylı bilgiye ulaşmak mümkündür. Ancak son y1llara ait istatistik yıllıklarında sinırlı sayıda hastalık için az sayıda veri yayınlanmaktadır.

Temel Sağlık Hizmetleri Genel Müdürlüğü'ne ait rutin istatistik yıllıkları 2006 yılı itibarıyla sonlandırılmış, 2007 yılına ait veriler paylaşılmamıştır. 2008 ile 2010 yılları arasında ise seçilmiş dokuz hastalığa ait vaka sayıları ve insidanslarına dair bilgiler paylaşılmış ve 2010 yılında seçilmiş on hastalık paylaşılmıştır.

2011 yılından itibaren yayınlanan BZBH'lerin sayısı azaltılarak 4'e (AIDS, Kızamık, Sıtma ve Tüberküloz) indirilmiştir.

Sağlık istatistik yıllıklarında "Yıllara Göre Bazı Seçilmiş Enfeksiyon Hastalıklarının İnsidansı" başlığı altında yayınlanan belirli hastalıklara yer verilip diğer hastalık verilerine yer verilmemesi olası bir salgın tehlikesinin saptanmasını zorlaştıracaktır.

Bulaşıcı hastalık bildirimlerinin amacı; bulaşıcı hastalık riski konusunda ilgili kurum ve kuruluşları uyarmak ve gerekli önlemlerin alınmasını sağlamaktır. Böylece bulaşıcı hastalıklar yayılıp salginlara neden olmadan kontrol altına alınarak, zarar azaltma çalışmaları yapılabilir.

Güvenilir olmadığı gerekçesiyle bu verilerin istatistik y1llıklarında yer almamas1 afet yönetimi açısından bulaşıcı hastalıklar konusunda tehlike ve risk analizlerinin yapılmasını ve afet planlarının gerçeğe uygun hazırlanabilmesini zorlaştırmaktadır.

Sağlık Bakanlığı istatistik yıllıkları incelendiğinde 1956-2017 yılları arasında en çok bildirimi yapılan 3 hastalık tüberküloz, sitma ve kizamıktır (Tablo 2).

Sağlık Bakanlığı istatistik yıllıklarında verisi yayınlanan bulaşıcı hastalıkların vaka sayıları dikkate alınarak önem sırasına göre afet yönetimi açısında analiz edecek olursak; 
Tablo 2. Sağlık İstatistik Yıllıklarında Bildirilen Bildirimi Zorunlu Hastalıklar ve Vaka Sayıları

\begin{tabular}{lcr}
\hline Hastalık Adı & Yayın Yılı & \multicolumn{1}{c}{ Vaka } \\
Sayıs \\
\hline 1. Tüberküloz & $1956-2017$ & 1.619 .779 \\
2. Sıtma & $1956-2017$ & 1.205 .716 \\
3. Kızamık & $1956-2017$ & 1.097 .329 \\
4. Tifo & $1956-2006$ & 442.759 \\
5. Dizanteri & $1956-2006$ & 356.058 \\
6. Hepatit A & $1987-2006$ & 351.913 \\
7. Brusellozis & $1956-2007$ & 281.530 \\
8. Kızıl & $1956-2005$ & 207.666 \\
9. Boğmaca & $1956-2010$ & 185.691 \\
10.Hepatit B & $1990-2010$ & 99.647 \\
11.Difteri & $1956-2010$ & 52.138 \\
12.Paratifo & $1956-2006$ & 32.396 \\
13.Şarbon & $1956-2007$ & 31.382 \\
14.Poliomyelit & $1956-2007$ & 15.508 \\
15. AIDS & $1985-2017$ & 1.531 \\
16. Kuduz & $1956-2007$ & 1.238 \\
17. Kolera & $1964-1974$ & 384 \\
18.Çiçek & $1956-1974$ & 128 \\
\hline
\end{tabular}

\section{Tüberküloz}

Türkiye'de 1956-2017 yılları arasında toplam 1.619.779 vaka sayısı ile bildirimi en çok yapılan hastalık tüberkülozdur (Tablo 2).

Türkiye'de aktif sürveyans ve dikey örgütlenme şeklinde hizmet veren Verem Savaş Dispanserlerinin çalışmaları sayesinde tüberküloz kaynaklı ölümlerin verileri diğer bulaşıcı hastalıklara oranla daha güvenilirdir. Tüberküloza bağlı 36.514 ölümün olduğu istatistik yıllıklarından tespit edilmiştir. Toplam bu süre içindeki ölüm verilerinin yer aldığ yıllar esas alındığında fatalite hızı \%5,9 olarak hesaplanmıştır. Tüberkülozdan korunmanın aşı ile mümkün olduğu ve tedavisi eksiksiz yapıldığında önlenebilir bir hastalık olduğu göz önüne alınırsa ölüm sayısı kabul edilemez düzeydedir.

Türkiye Verem Savaşı 2018 Raporu'na göre; 2016 yılı için fatalite hızı; tüm vakalarda $\% 5,7$, yeni vakalarda $\% 5,6$ ve önceden tedavi görmüş vakalarda $\% 5,9$ olarak bildirilmiştir. ${ }^{17}$

Araştırmada; 1956-2017 yılları arasında bildirilen toplam tüberküloz vaka sayıs1 1.619.779, ortalama yıllık vaka sayısı 26.125 ve ortalama insidans hızı da yüz binde 51 olarak tespit edilmiştir (Tablo 2 ve Tablo 3 ). Başka bir deyişle 1956-2017 yılları arasında
100.000 kişiden yaklaşık 51'i tüberküloz hastalığına yakalanmıştır.

Veriler analiz edildiğinde on y1llık ortalamanın en yüksek olduğu dönem 19601969 yılları arasıdır. Bu yıllar arasında yıllık ortalama vaka sayısının 48.264 ve insidans hızının da yüz binde 156 olduğu tespit edilmiştir. İnsidans hızının son yıllarda (20102017 yılları arasında) yüz binde 18'e düştüğü tespit edilmiştir. 2017 yılına gelindiğinde insidansın yüz binde 15 'e (11.821 vaka) düştüğü ve trendin aşağı yönlü olduğu tespit edilmiştir. Afet yönetimi bakış açısıyla değerlendirildiğinde bu düşüşler oldukça olumludur.

Dünya Sağlı Örgütü 1993 yılında tüberküloz için acil durum ilan etmiştir. Kontrol tedbirleri güçlendirilmediği takdirde 2020 y1lına kadar 1 milyardan fazla insanın tüberküloz basili ile enfekte olacağı, 200 milyon kişinin hasta olacağı ve 70 milyon kişinin hayatını kaybedeceği hesaplanmaktadır. ${ }^{18}$ Dünyadaki bütün tüberküloz hastalarının \%80'i 22 ülkededir. Hindistan, Bangladeş, Çin gibi ülkelerde tüberküloz insidansı 10.000'de 10'un üzerinde iken, Avrupa'da 10.000'de 2'nin altındadır. ${ }^{19} \mathrm{Bu}$ araştırmada Türkiye'deki tüberküloz insidansının düzenli ve sürekli azalarak 2017 yılında 10.000'de 1,5'e düştügü saptanmıştır.

$\mathrm{Bu}$ rakamlardan da anlaşılacağı üzere Türkiye'deki tüberküloz insidansı devamlı surette azalarak Avrupa ülkeleri seviyesine inmiştir. $\mathrm{Bu}$ başarıda Türkiye'de dikey örgütlenme şeklinde hizmet veren Verem Savaş Dispanserlerinin büyük önemi bulunmaktadır.

\section{Sitma}

Vaka sayısı açısından Türkiye'de afete neden olabilecek ikinci en önemli bildirimi zorunlu bulaşıcı hastalık sıtmadır (Tablo 2).

1956 yilında sitma eradikasyonu programının tatbikine esas olmak üzere Türkiye'nin tamamını kapsayan çalışmalar yapılmıştır. $\mathrm{Bu}$ çalışmalar sonucunda hazırlanan esaslar dâhilinde 1957 yılının başında Türkiye'de sıtma savaşı programı 
terkedilerek sitma eradikasyonu programına geçilmiştir.

Başlatılan eradikasyon programı ile beraber 1970'li yılların ortalarına kadar sıtma salgınları önlenmiştir. Ancak 1977 (yüz binde 274) ve 1994 (yüz binde 138) y1llarında eradikasyon programının esnetilmesinden dolayı sıtma salgını görülmüştür. 2008 yılından sonra sitma insidansı yüz binde 0'a düşmüştür. 2013 Sağlık istatistiği yıllığ verilerine göre; 2010, 2011, 2012 ve 2013 yılları yerli sıtma vakalarının tamamı nüks vaka olup yerli yeni vaka sayısı 0 'dır.

Araștırmada; 1956-2017 yılları arasında bildirilen toplam sitma vaka sayıs1 1.205.716, ortalama yıllık vaka sayısı 19.447 ve ortalama insidans hızı da 38 (yüz binde) olarak tespit edilmiştir. Başka bir deyişle 1956-2017 yılları arasında yüz bin kişiden yaklaşık 38'i sitma hastalığına yakalanmıştır (Tablo 3).

Veriler analiz edildiğinde on y1llik ortalamanın en yüksek olduğu dönem 19901999 yılları arasıdır. Bu yıllar arasında yıllık ortalama vaka sayısının 40.737 ve insidans hızının da 66 (yüz binde) olduğu tespit edilmiştir. Ancak sitma insidansı 70'l y yllarda yüz binde 74 'e, 80 'li yıllarda yüz binde 82 'ye çıktığı görülse de bu yıllara ait on y1llık ortalama, 90'l yilların ortalamasının altındadır. 2017 yılına gelindiğinde insidansın yüz binde 0'a (214 vaka) düştüğü ve trendin aşağı yönlü olduğu tespit edilmiştir. Afet yönetimi açısından bu düşüş oldukça olumludur.

Dünyada 106 endemik ülke ve bölgede 2010 yılında yaklaşık 216 milyon sitma vakası bildirilmiş olup bu vakaların yaklaşık 655 bini ölümle sonuçlanmıştır. Bu ölümlerin \%91'i Afrika bölgesinde ve 5 yaş altı çocuklarda görülmüştür. $^{20,21}$

Dünya Sağlı Örgütü verilerine göre; komşu ülkelerde sitmanın insidansı (binde); Irak, Suriye, Bulgaristan, Yunanistan ve Rusya'da 0 iken, İran'da 0,5'tir. Sitmanın en yaygın olduğu ülke Ekvatorya'dır (binde $238,8)$. $^{22,23}$
Tablo 3. Sağlık İstatistik Yıllıklarında Bildirilen Bildirimi Zorunlu Hastalıkların Ortalama İnsidans Hızları ve Yılık Ortalama Vaka Sayıları (1956 2017)

\begin{tabular}{lrr}
\hline Hastalık Adı & $\begin{array}{c}\text { Ortalama } \\
\text { Insidans } \\
\text { Hizı }^{\mathbf{1}}\end{array}$ & $\begin{array}{c}\text { Yıllık } \\
\text { Ortalama } \\
\text { Vaka Sayısı }\end{array}$ \\
\hline Tüberküloz & 51,0 & 26.125 \\
Sitma & 38,0 & 19.447 \\
Kizamık & 34,6 & 17.699 \\
Hepatit A & 27,8 & 14.208 \\
Dizanteri & 13,6 & 6.982 \\
Tifo & 13,6 & 6.964 \\
Brusellozis & 8,2 & 4.200 \\
Kizıl & 8,1 & 4.153 \\
Hepatit B & 7,7 & 3.957 \\
Boğmaca & 6,6 & 3.376 \\
Difteri & 2,2 & 1.109 \\
Paratifo & 1,2 & 635 \\
Şarbon & 1,0 & 529 \\
Poliomyelit & 0,5 & 244 \\
AIDS & 0,3 & $162^{2}$ \\
Kuduz & 0,04 & 21 \\
Kolera & - & - \\
Çiçek & - & - \\
\hline${ }^{1}$ Yüz binde, ${ }^{2}$ AIDS+HIV+ vaka sayısı & &
\end{tabular}

${ }^{1}$ Yüz binde, ${ }^{2} \mathrm{AIDS}+\mathrm{HIV}+$ vaka sayısı

\section{Kızamık}

Bu araştırmada, kızamık insidansının (yüz binde) en yükssek olduğu yılların sirasıyla; 1965 (169), 1966 (159), 1969 (192) y1lları olduğu, daha sonra 1970-1971, 1973, 1975, 1981, 1983-1984, 1993, 1996-1998, 2001 ve 2013 yıllarında da vaka sayılarında diğer yıllara göre anlamlı artışlar olduğu, vaka sayısının 60'lı yıllarda en yüksek olduğu ve özellikle 1965-1969 y1lları arasında salgınlar yaşandığı tespit edilmiştir.

Türkiye'de kızamık aşılama çalışmalarının düzenli olarak başladığı 1985 yılında kızamık insidans1 yüz binde 63'ten 30'a, takip eden iki yılda ise 4'e düşmüştür. Ancak, 1988 yılından itibaren aşlama oranlarının düşmesi ile birlikte vaka sayıları ve ölümlerde artışlar olduğu tespit edilmiştir. ${ }^{24}$

DSÖ 2013 yılında kızamık insidansının (yüz binde) Avrupa Bölgesi'nde 4,5, Avrupa Birliği Bölgesi'nde ise 1,7 olduğunu bildirmiştir. $^{25}$ Türkiye'de aynı yıllardaki kızamık insidansı, Avrupa Bölgesi ve Avrupa Birliği Ülkeleri'ne göre oldukça yüksektir. ${ }^{24}$ 


\section{Tifo}

Dünyada hâlâ yaygın ve önemini korumaya devam eden bir hastalıktır. Dünyada her yıl yaklaşık 16 milyon insan tifoya yakalanmaktadır. Tifo, Latin Amerika ve Afrika' da endemik olarak görülmektedir. ${ }^{26}$ Tifo, Türkiye'de de endemik olarak görülmekte ve zaman zaman salgınlara yol açmaktadir. ${ }^{27}$

Araştırmada; tifo insidansının (yüz binde 25) en yüksek olduğu 1960 yılından sonra insidansın azalmaya başladığı tespit edilmiştir.

1975 yılından sonra önemli düşüşler görülmesine rağmen 1980'li yıllardan sonra 2005 yılına kadar tifo insidansında önemli artışlar olduğu tespit edilmiştir. Ancak 2005 yılında bildirim sisteminin değişmesiyle birlikte tifo insidansında önemli düşüşler görülmektedir. 2007 yılından sonra yayınlanan istatistik y1llklarında tifo verilerine yer verilmemiştir (Tablo 2).

Güneydoğu Anadolu Bölgesi'nde tifo insidans1 2007 yılında yüz binde 56,29 ve 2008 yılında ise yüz binde 1,8 olarak bildirilmiştir. ${ }^{28}$ Veriler göz önüne alındığında Güneydoğu Anadolu Bölgesi'nin tifo insidansının Türkiye insidansının oldukça üzerinde olduğu tespit edilmiştir.

\section{Dizanteri}

1987-1994 yıllarını kapsayan sağlık istatistik yıllıklarından sonra amipli dizanteri ve basilli dizanteri olarak yayınlanmaya başlanmıştır. Sağlık istatistik yıllıkları incelendiğinde amipli dizanteri sayısının basilli dizanteri sayısından fazla olduğu tespit edilmiştir. Ancak araştırmada her iki dizanteri çeşidi de aynı başlık altında değerlendirilmiştir.

Toplam dizanteri vaka sayıs 356.058, y1llik ortalama vaka say1s1 6.982 ve ortalama insidans hızı da 15 (yüz binde) olarak tespit edilmiştir (Tablo 2 ve Tablo 3).

On yıllık ortalama vaka sayısının (21.484) ve insidans hızının (yüz binde 33) en yükssek olduğu dönem 2000-2009 yılları arasıdır.
Dizanteri 1990'l y yllardan başlayarak bir yükseliş trendine girmiştir.

Türkiye'de dizanteri insidansı konusunda yapılmış bir araştırmaya ulaşılamamıştır. Dünya'da Uzak Doğu, Orta ve Güney Amerika, Hindistan, Güney ve Batı Afrika bölgeleri yüksek insidans oranına sahip bölgeler olarak bilinmektedir. ${ }^{29}$ Olası bir dizanteri salgının da Türkiye'nin konumu ve dünyada gelişen olanaklardan dolayı sadece bulunduğu bölgeyi etkilemekle kalmayıp afet boyutuna bulaşabilme riski taşımaktadır.

\section{Hepatit A}

Gelişmekte olan ülkelerde endemiktir. Türkiye orta endemisite grubunda yer almaktadır. $^{30}$ Türkiye'nin hepatit A insidansında bölgesel farklılıklar vardır. Batı ve Orta Anadolu Bölgeleri hepatit A için orta endemisiteye sahip iken, Doğu Anadolu Bölgesi hala yüksek endemisiteye sahiptir. ${ }^{31}$

Araştırmada; toplam hepatit A vaka sayısı 351.913 , ortalama yıllık vaka sayıs 14.208 ve ortalama insidans hızı da 25 (yüz binde) olarak tespit edilmiştir (Tablo 2 ve Tablo 3 ).

Y1llık ortalama vaka sayısının (26.132) ve insidans hızının (yüz binde 53) en yüksek olduğu dönem 1980-1989 yılları arasıdır. Hepatit A insidans1 90'l1 yılarda yüz binde 32'ye, 2000'li y1llarda 13'e ve günümüzde 4'e düşmüştür. Afet yönetimi bakış açısıyla düşüş oldukça önemlidir.

\section{Brusella}

Türkiye'de hayvancılığın yaygın olarak yapılmas1, süt ve süt ürünlerinin tüketilmesinin fazla olmasi ayrica brusellozisin potansiyel bir biyoterörizm ve kitle imha silahı olarak kullanılma riski bu hastalığı afet yönetimi açısından önemli kilmaktadır.

Brusellozis, olası bir salgında can kayıplarına, sosyal ve ekonomik zararlara neden olacağından dolayı afet yönetimi açısından incelenmesini gerekli kılmaktadır.

Araştırmada; toplam brusellozis vaka sayıs1 281.530, yıllık ortalama vaka sayıs1 4.200 ve ortalama insidans hızı da 6 (yüz 
binde) olarak tespit edilmiştir (Tablo 2 ve Tablo 3).

On y1llık ortalamanın en yüksek olduğu dönem 2000-2009 yılları arasıdır. Bu yıllar arasında yıllık ortalama vaka sayısının 13.314 ve insidans hızının da 20 (yüz binde) olduğu tespit edilmiştir. $\mathrm{Bu}$ sayının son yıllarda (2010-2017 yılları arasında) (yüz binde) 8'e düştüğü tespit edilmiştir. 2017 yılına gelindiğinde insidansin 8 (yüz binde) olduğu (6457 vaka bildirildiği) bu oranın da y1llık ortalamaya denk geldiği tespit edilmiştir. Veriler incelendiğinde son yllda trendin yine yukarıya doğru olduğu belirlenmiştir. Afet yönetimi bakış açısıyla değerlendirildiğinde bu yükseliş değerlendirilmeli ve brusellozis ile etkin bir şekilde mücadele edilmelidir.

\section{Kızıl}

Araştırmada; ortalama yıllık kızıl vaka sayıs 4.153 ve ortalama insidans hizı da 8 (yüz binde) olarak tespit edilmiştir (Tablo 2 ve Tablo 3).

Veriler analiz edildiğinde on y1llık ortalamanın en yüksek olduğu dönem 19801989 yılları arasıdır. Bu yıllar arasında yıllık ortalama vaka sayısının 7.376 ve insidans hızının da 15 (yüz binde) olduğu tespit edilmiştir.

\section{Boğmaca}

Dünyada ve Türkiye'de salgına neden olabilecek ve hâlâ tüm yaş gruplarını tehdit eden önemli bulaşıcı hastalıklardan biridir. Boğmaca, 2-5 yılda bir salgınlara neden olduğu için afet yönetimi açısından önemlidir.

Araştırmada; boğmaca yıllık vaka sayısı 3.376 ve ortalama insidans hızı da 7 (yüz binde) olarak tespit edilmiştir (Tablo 2 ve Tablo 3). İnsidansın en yüksek olduğu dönem 1960-1969 yılları arasıdır. ${ }^{32} \mathrm{Bu}$ yıllar arasında y1llı ortalama vaka sayısının 9.319 ve insidans hızının da 30 (yüz binde) olduğu tespit edilmiştir.

\section{Hepatit B}

Araştırmada; Hepatit B verilerinin 1990 yılından sonra yayınlanmaya başladığı, ortalama yıllık hepatit B vaka sayısının 3.957, ortalama insidans hızı da 6 (yüz binde) olduğu tespit edilmiştir (Tablo 2 ve Tablo 3). Ortalama vaka sayısının (5.995) ve insidans hızının (yüz binde 9) en yüksek olduğu dönem 2000-2009 y1lları arasıdır.

İnsidansın son y1llarda yüz binde 4'e düştüğü ve trendin aşağı yönlü olduğu tespit edilmiştir. Afet yönetimi açısından bu düşüş oldukça olumludur.

\section{Difteri}

Dünyada ve Türkiye'de salgına neden olabilecek ve hâlâ tüm yaş gruplarını tehdit eden önemli bulaşıcı hastalıklardan biridir. Veriler değerlendirildiğinde belli dönmelerde (1982-1985, 1990-1995) salgın yaptığından dolayı afet yönetimi açısından incelenmelidir.

Araştırmada; ortalama yıllık difteri vaka sayıs1 1.109 ve ortalama insidans hizı da 4 (yüz binde) olarak tespit edilmiştir (Tablo 2 ve Tablo 3). Yillık ortalama vaka sayısının (4.243) ve insidans hızının (yüz binde 16) 1956-1959 yılları arasında en yüksek olduğu tespit edilmiştir.

Difterinin, Rusya'da 1991 ile 1993 yıllarında salgın yaptığ ve insidansın yüz binde 10,2 'ye ulaştığı bildirilmiştir. ${ }^{33}$ Türkiye'de 1991 ile 1993 yillarında difteri insidans hızında ciddi bir artış olmamıştır.

\section{Paratifo}

Araştırmada; toplam paratifo vaka sayısı 32.396, yıllık ortalama vaka sayısı 635 ve ortalama insidans hızı da 1,2 (yüz binde) olarak tespit edilmiştir (Tablo 2 ve Tablo 3).

2001-2005 y1llar1 arasinda paratifo vakalarında önemli düşüşler olduğu tespit edilmiştir. Bildirim sisteminin değiştirilmesiyle beraber 2006 yılından sonra istatistik yıllıklarında paratifo verileri yer verilmemiştir.

\section{Şarbon}

Dünya üzerinde endemik bölgeler; Güney Amerika, Orta Amerika, Güney ve Doğu Avrupa, Asya, Afrika, Karayipler ve Orta Doğu'dur. ${ }^{34}$

Araştırmada; toplam şarbon vaka sayısı 31.382, yıllık ortalama vaka sayıs1 529 ve 
ortalama insidans hızı da 1 (yüz binde) olarak tespit edilmiştir (Tablo 2 ve Tablo 3 ).

Yıllık ortalama vaka sayısinın (987) en yüksek olduğu dönem 1960-1969 y1lları arasıdır. $\mathrm{Bu}$ yıllar arasında yıllık ortalama insidans hızının da 3 (yüz binde) olduğu tespit edilmiştir. Ancak şarbon insidansının en yüksek olduğu dönem 1956-1959 yıları arasıdır. İnsidansın son yıllarda neredeyse yüz binde 0'a düştüğü (37 vaka) ve trendin aşağ yönlü olduğu tespit edilmiştir.

\section{Poliomyelit}

Dünyada ve Türkiye'de salgına neden olabilecek çocukluk çağı önemli bulaşıcı hastalıklardan biridir.

Dünyada poliomyelit aşısına 1950'lerin ortalarına doğru başlanmıştır. $\mathrm{Bu}$ aşılamayla beraber hastalığın vaka sayısında önemli düşüşler sağlanmıştır. 1988 yılına gelindiğinde DSÖ, 2000 y1lına kadar tüm dünyada poliomyelitin eradikasyonunu hedeflemiş, ${ }^{35}$ aksamalar nedeniyle 2005 yılına kadar uzatılmıştır. ${ }^{36}$ Ancak istenilen hedefe ulaşılamayınca yeni hedef olarak 2015 sonu belirlenmiştir. Yine de bu hastalık eradike edilememiştir.

Araştırmada; ortalama yıllık poliomyelit vaka sayısı 244 ve ortalama insidans hızı da 1 (yüz binde) olarak tespit edilmiştir (Tablo 2 ve Tablo 3). Ortalama vaka sayısının (908) ve insidans hızının 3 (yüz binde) en yüksek olduğu dönem 1960-1969 yılları arasıdır.

1964-1968 yılları arasında poliomyelit ortalama insidansının (yüz binde) Bulgaristan'da 0,04, Fransa'da 0,50, Yunanistan'da 0,77, Portekiz'de 1,45, İtalya'da 0,65 olduğu bildirilmiştir. ${ }^{37}$ Türkiye'de bu y1llar arasında poliomyelit insidansı belirtilen ülkelere göre çok daha yüksektir. Bu durum, Türkiye'nin o yıllarda poliomyelit ile mücadelede yetersiz kaldığını göstermektedir.

\section{AIDS}

Kesin bir tedavi yönteminin olmayışı, kullanılan ilaçların enfekte bireyin yaşam süresini ve kalitesini arttırmaya yönelik olmas1, toplumda sosyal, ekonomik, insan hakları ve ayrımcılık gibi sorunları beraberinde getiriyor olması, dünyada HIV/AIDS vaka bildirimlerinin hizla artiyor olması, beklenmeyen boyutlara ulaşma riski taşıması nedeniyle AIDS afet yönetimi açısından önemlidir.

Araştırmada; 1956-2017 yılları arasında bildirilen toplam AIDS vaka sayisının 1.531, yıllık ortalama vaka sayısının 46 ve yıllık ortalama HIV+ vaka sayısının da 116 olduğu tespit edilmiştir (Tablo 2 ve Tablo 3 ).

Y1llik ortalama vaka sayısının (95) en yüksek olduğu dönem 2010-2017 y1lları arasıdır ve trend yukarı yönlüdür. Afet yönetimi açısından bu trend değerlendirilmeli ve AIDS ile etkin bir şekilde mücadele edilmelidir.

Ancak 2010 y1lından sonra yayınlanan istatistik yıllıklarında HIV+ sayılarının verilmeyişi hastalığın seyrinin belirlenmesinde zorluklara neden olmaktadır.

AIDS insidans1, Avrupa Bölgesi'nde 20142015 yılları arasında yüz binde 1,8, Avrupa Birliği ülkelerinde yaklaşık 1 'dir. ${ }^{38}$ AIDS salgını açısından Türkiye bu ülkelere göre daha düşük riske sahiptir.

\section{Kuduz}

Rabies virüsünün neden olduğu bilinen en eski zoonotik enfeksiyon hastaliklarından biridir. Dünyada ve Türkiye'de önemini hala koruyan bir halk sağlığı sorunudur. ${ }^{39}$

Araştırmada; toplam kuduz vaka sayısının 1.238 ve yıllık ortalama vaka sayısının 21 olduğu ve tüm vakaların ölümle sonuçlandığ tespit edilmiştir (Tablo 2 ve Tablo 3).

Yıllık ortalama vaka sayısının (47) en yüksek olduğu dönem 1956-1959 yılları arasıdır. Vaka sayısının son yillarda 0'a düştüğü, ancak 2017 yılında 2 vaka olduğu tespit edilmiştir. Trendin aşağ 1 yönlü olması afet yönetimi açısından oldukça olumludur.

\section{Kolera}

Kolera vaka sayıları coğrafyamızda birçok kez afet boyutuna ulaşmıştır. Ancak istatistik yıllıklarında sadece 1970 yılına ait 384 vaka yayınlanmıştır. 
eradike edilmiş olup Türkiye'de de 1957

\section{Çiçek}

Çiçek hastalığı birçok kez salgın oluşturmasına rağmen, yıllıklarda sadece 1957 yılına ait 128 vaka yayınlanmıştır (Tablo 2). Çiçek hastalığı 1979 yılında dünyada yılından sonra vaka bildirimi yapılmamıştır. Ancak virüsün laboratuvarlarda saklandığı ve biyolojik silah olarak kullanılma riski olduğu bilinmektedir. ${ }^{40}$

\section{SONUÇ VE ÖNERILER}

Yasal zorunluluk olmasına rağmen, Türkiye'de, bildirimi zorunlu bulaşıc1 hastalıkların bildirimleri yeterli düzeyde değildir. Eksik veriler bulaşıcı hastalıklarla mücadelede uygun stratejilerin belirlenmesini engellemektedir.

2004 ve öncesine ait sağlık istatistik yıllıkları incelendiğinde eski yıllara ait yıllıklarda hastalıkların verilerine daha çok önem verildiği görülmektedir. Eski tarihli yıllıklarda; hastalığın salgın yaptığı yıllar, hastalıkla mücadelede yapılan uygulamalar ve aksayan yönleri, hastanede yatıp tedavi gören ve hastanede hayatını kaybeden vakalara ait verilere de yer verilmekte, iller ve mevsimler bazında daha detaylı bilgiye ulaşmak mümkün iken; son yıllara ait istatistik yıllıklarında sınırlı sayıda hastalık için az sayıda veri yayınlanmıştır.

Sağlık Bakanlığı istatistik y1llıkları incelendiğinde 1956-2017 yılları arasında en çok bildirimi yapılan 3 hastalık tüberküloz, sitma ve kızamıktır.

$\mathrm{Bu}$ sonuçlar doğrultusunda şu öneriler yapılabilir;

1. Etkili ve kapsamlı bir sürveyans, erken yanıt ve müdahale altyapısı oluşturmalı, oluşturulan bu alt yap1 sistemleri hükümetler, Birleșmiș $\quad$ Milletler kuruluşları, özel sektör kuruluşları ve teşkilatları, mesleki dernekler, üniversiteler, medya organları ve sivil toplum arasında küresel işbirliğine dayanmalidir.

2. Sağlık istatistik yıllıklarında tüm bulașıcı hastalık verileri yer almalı, gerekli diğer bilgiler de paylaşıma açılmalıdır.

3. Her ilin Sağlık Müdürlügü web sayfasında o ildeki bulaşıcı hastalık vaka sayılarının yayınlanması sürveyans açısından oldukça gereklidir. DSÖ'nün önerisi de bu yöndedir.

4. Türkiye'de uygulanan sağlik afet ve acil durum planlarının içeriğinde bulaşıcı hastalıklara da yer verilmelidir.

5. Bulaşıcı hastalık ajanlarının biyolojik silah olarak kullanılma riskinin yüksek olduğu ve afetlere neden olabileceği unutulmamalıdir.

6. Olası bulaşıcı hastalık salgınlarına (biyolojik afetlere) karşı önlemler alınmalıdır. Biyolojik bir afet meydana geldiğinde de en az zararla atlatmak için sürekli planlar yapılmalı ve mevcut şartlara göre planlar güncellenmelidir.

KAYNAKLAR

1. Güler, H.H. (2006). Afetlere Hazırlıklı Olma. Kadıoğlu, M. ve Özdamar, E. 2. Baskı. Afet Yönetiminin Temel İlkeleri. Ankara: JICA Türkiye Ofisi Yayınları.

2. Akın, L. ve Güler, Ç. (2006). Halk Sağlığı Temel Bilgiler. Hacettepe Üniversitesi Yayınları. Ankara

3. Heymann, D.L, Prentice, T. and Reinders, L.T. (2007). The world health report 2007: A safer future: global public health security in the 21 st century. World Health Organization.

4. T.C. Sağlık Bakanlığı. (2015). "Bulaşıcı Hastalıkların İhbar ve Bildirim Sistemi”. Erişim Adresi: https://hsgm.saglik.gov.tr/ dosya/mevzuat/genelge/2015_18.pdf, (Erişim Tarihi: 15.03. 2019)

5. T.C Sağlık Bakanlığı. (2018). "İzci, Bulaşıcı Hastalık Sürveyans ve Erken Uyarı Sistemi, Kullanım Talimatnamesi”. Erișim adresi: https://dosyaism.saglik.gov.tr/Eklenti/59773,kilavuzpdf. pdf?0, (Erişim Tarihi: 15.03.2019).

6. T.C. Sağlık Bakanlığı. (2018). "İstatistik Yıllıkları”. Erişim Adresi: https://www.saglik.gov.tr/TR,11588/istatistikyilliklari.html. (Erişim tarihi: 21.03.2019).

7. T.C. Sağlık Bakanlığı Sağlık İstatistikleri Yıllığı 1956-1959. (1961). Ankara

8. T.C. Sağlık Bakanlığı Sağlık İstatistikleri Yıllığı 1960-1963. (1965). Ankara

9. T.C. Sağlık Bakanlığı Sağlık İstatistikleri Yıllığı 1964-3967. (1971). Ankara.

10. T.C. Sağlık Bakanlığ Sağlık İstatistikleri Y1llığ1 1968-1972. (1975). Ankara. 
11. T.C. Sağlık Bakanlığı Sağlık İstatistikleri Yıllığı 1973-1974 (1977). Ankara.

12. T.C. Sağlık Bakanlığı Sağlık İstatistikleri Yıllığı 1975-1978. (1980). Ankara.

13. T.C. Sağlık Bakanlığı Sağlık İstatistikleri Yıllı̆̆ 1979 - 1981 (1983). Ankara.

14. T.C. Sağlık Bakanlığı Sağlık İstatistikleri Yıllığı 1982-1986. Ankara.

15. T.C. Sağlık Bakanlığı Sağlık İstatistikleri Yıllığı 1987-1994. (1997). Ankara.

16. T.C. Sağlık Bakanlığg Sağlık İstatistikleri Yıllığı 1995. (1996). Ankara.

17. T.C. Sağlık Bakanlığı. (2018). Türkiye’de Verem Savaşı 2018 Raporu. Ankara. Sağlık Bakanlığı Yayın No: 1109.

18. Dünya Sağlık Örgütü. (2018). Global Tuberculosis Report 2018. Geneva: World Health Organization. ISBN 978-92-4-156564-6.

19. WHO. (2002). Global Tuberculosis Control. Surveillance, Planning, Financing. Communicable Diseases. Geneva: World Health Organization. WHO/CDS/TB/2002.295

20. World Health Organization. (2011). WHO Global Malaria Programme. Geneva. Switzerland: WHO Press.

21. World Health Organization. (2008). World malaria report 2008 WHO Press. Geneva. Switzerland

22. WHO. (2017). "World malaria report 2017”. Erişim adresi http://www.who.int/malaria/publicati ons/worldmalaria-report2017/wmr2017- annex-table-h.xls?ua= (Erişim tarihi:18.03. 2019)

23. Bertan, M. ve Akın, L. (1997). Bağıșıklama, Halk Sağlığı Temel Bilgiler. Ankara: Güneş Kitabevi.

24. HASUDER (Halk Sağlığı Uzmanları Derneği). (2013). "Kizamık Raporu 2013", Ankara.

25. WHO. (2013). "Measles Fact sheet”. No:286. Erişim adresi: http://www.who.int/mediacentre/factsheets/fs286/en/

26. Crump, J.A. and Mintz E.D. (2010). "Global trends in typhoid and paratyphoid fever". Clin Infect Dis, 50, 241-6. Erişim adresi: http://dx.doi.org/10.1086/649541PMid:20014951 PMCid:2798017

27. Akın, L. (1995). Bulaşıcı Hastalıkların Kontrol. Halk Sağlığı Temel Bilgiler Kitabı içinde (Ed. Bertan, M. ve Güler, C..). Ankara: Güneş Kitabevi.
28. Ertem, M. (2016). "GAP'ın Topluma ve Bulaşıcı Hastalıklara” Etkisi. Erişim adresi: https://www.academia.edu/20400643 (Erișim tarihi: 28.03.2019)

29. Stauffer, W, Abd-Alla, M. and Ravdin, J.I. (2006). "Prevalence and İncidence of Entamoeba Histolytica İnfection in South Africa and Egyp". Arch Med Res, 37 (2), 266-275.

30. Kara, H.İ. (2007). “Akut Viral Hepatit A.” Türk Aile Hek Dergisi, 11 (4), 177-184.

31. Ceyhan, M. Yıldırım, I. Kurt, N. Uysal, G. Dikici, B. and Ecevit, C. (2008). "Differences in Hepatitis a Seroprevalence Among Geographical Regions in Turkey: a Need for Regional Vaccination Recommendations". J Viral Hepat, 15, 69-72.

32. Dilli, D, Dallar, Y, Önde, U, Doğan, F. ve Yağcı, S. (2008) "Ergenlerde kızamık, kızamıkçık, kabakulak ve suçiçeği seroprevalansı”. Çocuk Dergisi, 8 (3), 172-178.

33. T.C. Sağlık Bakanlığı. (2003). Difteri Hastalığının Kontrolü İçin Saha Rehberi. Ankara: Sağlık Bakanlığı

34. Serinken, M. ve Kutlu S.S. (2009). "Bioterrorism and anthrax". Türkiye Acil Tıp Dergisi-Turk J Emerged Med, 9 (4), 18581990.

35. Hull, H.F, De Quadros, C, Bilous, J, Oblapenko, G, Andrus, J. and Aslanian, R. (1999). "Perspectives from the Global Poliomyelitis Eradication Lnitiative". MMWR, 48, 50-56.

36. Genç, M, Pehlivan, E, Güneş, G. ve Karaoğlu, L. (1999). "Malatya'daki Sağlık Personelinin Ulusal Așı Günleri Hakkındaki Bilgi ve Uygulamaları". Sağlık ve Toplum Dergisi, 4, 26-31.

37. Gemicioğlu, N. ve Arı, A. (1970). “1960 - 1969 Yılları Arasında Yurdumuzda Polio İle İlgili Laboratuvar Çalışmaları ve Yapılan İncelemeler”. Ankara Mikrobiyoloji Derneği, s.13.

38. Halk Sağlığı Genel Müdürlüğü. (2017). DSÖ European Health Information Gateway.

39. Buzgan, T, Irmak, H, Y1lmaz, G.R, Torunoğlu M.A. and Safran, A. (2009). "Epidemiology of human rabies in Turkey: 19922007’. Turk J Med Sci, 39 (4), 591-597.

40. Yeșilbağ, K. (2002). "Biyolojik Silahlar: I. Tehdidin Boyutu". Veteriner Hekimleri Mikrobiyoloji Dergisi, 2 (2), 58-66. 